\title{
PHYSIOLOGICAL QUALITY AND AFLATOXINS PREVALENCE IN CONVENTIONAL AND TRANSGENIC SOYBEANS DURING STORAGE
}

\author{
QUALIDADE FISIOLÓGICA E PREVALÊNCIA DE AFLATOXINAS EM SEMENTES \\ DE SOJA CONVENCIONAL E TRANSG ENNICA DURANTE O ARMAZENAMENTO
}

\section{Lúcia Helena Pereira NÓBREGA ${ }^{1}$; Claudia Tatiana Araújo da CRUZ SILVA² Adriana Maria MENEGHETTI ${ }^{3}$; Jaqueline SENEM ${ }^{2}$; Michelle TONINI²; Joseli Viviane Ditzel NUNES ${ }^{2}$}

1. Engineering Agronomist, Assistant Professor - Postgraduation in Agricultural Engineering, Western Paraná State University (UNIOESTE), Cascavel, PR, Brazil. Corresponding author: lucia.nobrega@ unioeste.br. 2. PhD - Postgraduation in Agricultural Engineering - UNIOESTE - Brazil. 3. Chemistry Bachelor Degree - PhD Professor - Federal Technological University of Paraná - Bachelor Degree in Biological Sciences. Chemistry area. Santa Helena - PR -Brazil

\begin{abstract}
Physiological quality of soybean seeds of five varieties (CD 215, CD 202, CD 233RR (GMO), NK and NK 412113 7059RR (GMO)), stored under cooling and room temperature during eight months as well as B1, B2, and G2 aflatoxins prevalence were evaluated. The tests (moisture content, germination, tetrazolium) were performed before storage and every 60 days. The analysis of aflatoxins presence was carried out at the beginning and at each two months. Two samples of each variety were stored at $-4{ }^{\circ} \mathrm{C}$ until analysis processing, then high-performance liquid chromatography analysis was used. The seeds showed, in general, water content between 11 and 13\% until 60 storage days, whose decrease began up from 120 days. At 60 storage days, the cooled seeds had higher germination percentage when compared to the ones kept under room temperature. In relation to the studied varieties, the highest germination was recorded for CD 215, which differed from CD 202 in both periods. There were factors interactions after 120 and 240 storage days, especially under cooling to 120 days for CD 215 variety. While, at 240 days under room temperature was observed the highest germination for the CD $233 \mathrm{RR}$. The storage conditions were significant at 60, 180 and 240 days for viability, with a higher rate for seeds stored under cooling. Regarding varieties, over the same periods, the CD 202 variety showed lower viability percentage, with NK 412113 after 180 and 240 days. In general, 90 samples were tested and, 25 were detected the aflatoxins presence. It was observed that the aflatoxins presence in CD 202 was quantitatively greater from 16 tested samples 10 showed some level of aflatoxin contamination. AFB1 and AFB2 aflatoxins represented 50\%, while AFG2 was observed in $63 \%$ of those samples. There was no difference in relation to seed vigor between conventional or transgenic soybeans seeds. Cooling kept the vigor of CD 215 and CD 233RR varieties until the final of the experiment. There was no influence by the storage to get aflatoxins and temperature association.
\end{abstract}

KEYWORDS: Germination. Glycine $\max$ (L.) Merrill. Mycotoxins. Temperature.

\section{INTRODUCTION}

Soybean takes part of healthy foods whose claims have been widely disseminated by the media, due to its chemical and nutritional characteristics that qualify it as functional food. It is rich in protein, contains substances that help reducing risk of chronic and degenerative diseases. It is also a source of minerals like iron, potassium, magnesium, zinc, copper, phosphorus, manganese and $\mathrm{B}$ vitamins (CARRÃO-PANIZZI; MANDARINO, 1998; PENHA et al., 2007).

The soybean is cropped especially in Midwestern and Southern Brazilian regions, and it has been established as one of the head products of the national agriculture and trade balance. Advances in this area also enabled the increase in average yield per hectare and reached the major world indices (MAPA, 2012). Seed quality is assigned to a set of attributes that can be divided into genetic, physical, physiological and health. The physiological attributes are related to potential seed for germination, dormancy and vigor. The healthy attributes include healthy seeds and free of pathogens. Infected seeds by diseases may not show viability or they can show low vigor (PESKE; ROSENTHAL; ROTA, 2003).

Seeds with high water content are vulnerable to insects and fungi attack, as these organisms use the available water to survive and their development accelerates quickly under ideal conditions of temperature and humidity, with a 
Physiological quality...

decrease of safe storage period (LUZ, 2007). Seeds, whose viability is decreased, are susceptible to fungal attack, thus, more susceptible to deterioration process. The chemical changes which occur in seeds during storage are very slow, and sometimes even insignificant at low temperatures (SILVA, LACERDA FILHO; DEVILHA, 2000), so the main factors have affected soybean storage capacity include environment, relative humidity, water content, temperature and storage period (KONG et al., 2008).

Viability is an intrinsic factor of each seed and varies among species and varieties. The genetic factor of each variety has highly significant effect on seed storage potential. This suggests that more vigorous soybean seeds could show better results during storage. All the stresses seeds are submitted before, during and after harvest affect the storability (PESKE; ROSENTHAL; ROTA, 2003). Fungi are among the main deterioration causes of stored seeds, surpassed only by insects (ELIAS; OLIVEIRA, 2009). The fungi presence may indicate contamination by mycotoxins. Mycotoxins are toxic substances produced by fungi, and have contaminated several kinds of foodstuff, including soybean and its sub products (MÜRMANN et al., 2007). Mycotoxins associated with grains are a major cause of non-compliance in relation to safe food and impurities and/or strange matter (OLIVEIRA; LORINI; MALLMANN, 2010).

Seeds behavior knowledge, in relation to storage conditions which it is submitted, is important to evaluate its storability, a produced issue of great concern in Brazil. In this context, this study evaluated the physiological quality of soybean seeds from five varieties, conventional and transgenic. They were stored under cooling and room temperature to determine the prevalence of B1, B2, G1 and G2 aflatoxins.

\section{MATERIAL AND METHODS}

Analyses were carried out at Western Paraná State University - UNIOESTE, Campus Cascavel - PR. The seeds were provided by Cooperativa Agroindustrial Lar. Storage took place at the cooperative's Seed Laboratory, the cooling room and Seed Processing Unit were in Medianeira city, Paraná Western, at $25^{\circ} 17^{\prime} 40$ "south latitude and $54^{\circ} 05^{\prime} 30^{\prime \prime}$ longitude west. The weather is humid subtropical with hot summers, annual average temperature of $21^{\circ} \mathrm{C}$, whose annual average rainfall is $1880 \mathrm{~mm}$.

After harvesting, soybean seed samples of CD 215, CD 202, CD 233RR (GM), NK and NK
NÓBREGA, L. H. P. et al

412113 7059RR (GM) varieties were collected, in $2009 / 2010$ crop year which were produced in Xanxerê city, Western Region of Santa Catarina, where the Seed Processing Unit is placed. The seeds were packed in multiwall paper bags of $40 \mathrm{~kg}$ and submitted to two storages conditions: environmental condition (simulating a non-air-conditioned storehouse) and cooling (controlled temperature at $20 \pm 2{ }^{\circ} \mathrm{C}$ ) for eight months. Initially and every two months, two samples of each variety were separated and stored at $-4{ }^{\circ} \mathrm{C}$ until the analyses processing to record mycotoxins presence. Quality tests were carried out before storage, and at every 60, 120, 180 and 240 days at the Analyses Laboratory of Seeds and Plants and are described below:

Water content: determined by oven method oven, according to the Rules for Seed Analysis (BRASIL, 2009). The water content was expressed in percentage.

Germination test: four replications of 50 seeds for each sample were germinated in paper substrate ("germitest"), previously soaked in water, using 2.5 times the mass of dry paper soaked in water, wrapped and taken to the germination chamber at $25{ }^{\circ} \mathrm{C}$. After eight days, the percentage of normal seedlings, abnormal and dead seeds were evaluated. It was adapted from the criteria established by the Rules for Seed Analysis - RAS (BRASIL, 2009).

Tetrazolium test: determined by methodology of França Neto et al (1988) and classified according to viability and vigor.

Aflatoxin pattern: The aflatoxins presence was verified in five soybeans varieties, submitted to two storage conditions (room temperature and cooling) during five evaluation periods $(0,60,120$, 180 and 240 days), with two replications of each sample, totaling 90 samples, because, there was no cooling condition in the first period, consequently, no results were obtained. The standards preparation was carried out as recommended by the AOAC (2000). Aliquots of $200 \mu \mathrm{L}, 500 \mu \mathrm{L}, 500 \mu \mathrm{L}$, and $200 \mu \mathrm{L}$ of each standard bottle were withdrawn (Chiron Standard) of B1, B2 and G2 aflatoxins, respectively, adding until $10 \mathrm{~mL}$ with acetonitrileforming stock solution. The contamination standard solutions were prepared according to AOAC (2000) at concentrations which were similar to those expected in the samples to be analyzed. The stock solution of four aflatoxins mixture gave rise to the four points of calibration. The curve was prepared with individual patterns from the solution-stock. The standard concentrations of calibration curve were 40, 25, and 40 ngmL-1 aflatoxins B1, B2, G2, respectively. 
Extraction, purification and derivatization of samples: From the analytical sample, after removing them from cooling, seeds were milled, then sieved and uniformed, and stored again in refrigerator until they were ready to be analyzed. Fifty samples (300 g) were used. The analyses were carried out in triplicate, totaling 150 samples and extraction and derivatization methods followed the official AOAC method (994.08). Two $50 \mathrm{~g}$ aliquots of each sample were weighed and then acetonitrile-water was added and homogenized for one hour. Then, filtration was proceeded to be purified.

The immunoassay screening methodology was used to purification, with solid phase extraction (Manifold) in the system comprising by 12 columns with air flow maintained by pneumatic pump and flow regulators individualized for each column under flow rate of $2 \mathrm{~mL} \mathrm{~min}^{-1}$. In derivatization, 200 $\mu \mathrm{L}$ of purified extract were transferred and derivatization reactive (trifluoracetic- acetic acid water) was added, agitated by turbulence, heated, and injected into the chromatographic column. Chromatographic conditions and analyses: In order to detect aflatoxins, the screening method was already used as described above for immunoassay. The method consists in passing food extract through the column. While almost all of extract compounds are washed and eluted from the column, mycotoxins are retained and removed with organic solvents such as methanol or acetonitrile. This eluate contains mycotoxins in high concentration and purity, which can be detected by chromatographic methods (CAVALIERI et al., 2007).

The chromatogram analyses were made from four aflatoxin solutions injected into high performance liquid chromatography (HPLC) at concentrations considered as detection limits, and determined by the display of visible concerning the lowest concentration of each peak generated for each aflatoxin. The aflatoxin amount was recorded in HPLC with fluorescence detection (excitation $\lambda=360 \mathrm{~nm}$ and emission $=460 \mathrm{~nm} \mathrm{\lambda )} \mathrm{C18} \mathrm{column}$

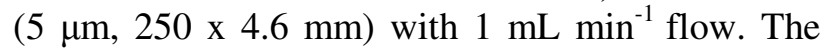
mobile phase was water: methanol: acetonitrile $(62: 22: 16 \mathrm{v} / \mathrm{v} / \mathrm{v})$ at $40{ }^{\circ} \mathrm{C}, 0.8 \mathrm{~L}$ min flow and $10 \mu \mathrm{L}$ injection volume. For each liter of mobile phase, $119 \mathrm{mg}$ of potassium bromide and $350 \mu \mathrm{L}$ of $4 \mathrm{M}$ nitric acid were added into it. The post-column derivation was made with the electrochemical cell (Cell KOBRA®).

The technique of external standard was used for chromatograph calibration. The calibration curve was obtained with aflatoxin standard solution with $10 \mathrm{uL}$ injection of both patterns and samples using HPLC system - DFL. It was applied the following equation to know the amount of mass in the injected samples:

$$
\begin{aligned}
& \frac{50 g \times 0.2}{100 m L} \times \frac{0.05}{0.9 m L}=0.005555 g \\
& n g \mathrm{~g}^{-1}(p p b)=\frac{n g \text { of injected toxins }}{0.005555 g}
\end{aligned}
$$

The mean retention times were determined for each aflatoxin, the chromatograms generated from the standard curve and the contaminated sample were visually compared to determine whether there was variation in retention times. The prepared samples were stored in refrigerator at \pm 10 ${ }^{\circ} \mathrm{C}$, and stayed for about two months before evaluation in HPLC. Samples, standards and reagents used should be stable during a reasonable period to produce reliable and reproducible results (SHABIR, 2003).

Experimental design: For the storage experiment, the experimental design was completely randomized, with four replications, in a $5 \times 2$ factorial (five varieties and two storage conditions), in each period. Statistical analysis was performed by analysis of variance (ANOVA) using statistical software SISVAR (FERREIRA, 2008). Seeds quality results were expressed in percentage and transformed in arc sen $\sqrt{x} / 100$ before being subjected to analysis of variance. When there were significant interactions, interaction sliced between factor 1 and factor 2 and comparisons among averages were obtained by Tukey test at 5\% probability. The data regarding tetrazolium test, which did not present normality by Minitab 14 program, were transformed in $\sqrt{x}+1$. Data whose coefficient of variation (CV) was lower than $20 \%$ were classified as low or medium, and considered homogeneous (PIMENTEL GOMES, 2000).

During the trial, five collection periods were carried out. The first one was considered the control (April, June, August, October, December). But, in relation to aflatoxins, the samples were classified by positive or negative detection.

\section{RESULTS AND DISCUSSION}

The determination of seed water content was performed for initial characterization of cultivars and to observe possible influence on the results, so it was not proceeded statistical analysis. Water content values of five soybean cultivars at harvest (time 0) and during storage periods are shown on Table 1. There, it can be observed that the answers of water content were between 11 to $13 \%$ from the beginning until 60 storage days. This 
condition is favorable to provide a satisfactory storage (HARRINGTON, 1972).

However, after 120 storage days, the seeds water content has reduced a lot in both room temperature and cooling conditions. At room conditions, the results were higher than in cooling conditions at 180 and 240 storage days and this could be due to greater variation of psychometric conditions of storage environment. The seeds water content can change due to air humidity fluctuations under room conditions and, when associated to temperature variations, it can determine seed quality reduction.

Table 1. Seeds water content (\%) of five soybean varieties, after harvest (initial data) and four storage periods under room temperature (A) and cooling (C) conditions.

\begin{tabular}{|c|c|c|c|c|c|c|c|c|c|}
\hline \multirow{4}{*}{ Varieties } & \multirow{4}{*}{0} & \multicolumn{8}{|c|}{ Storage Periods (days) } \\
\hline & & \multirow{2}{*}{\multicolumn{2}{|c|}{60}} & \multirow{2}{*}{\multicolumn{4}{|c|}{$\begin{array}{lc}120 & 180 \\
& \text { Storage Conditions }\end{array}$}} & \multicolumn{2}{|l|}{240} \\
\hline & & & & & & & & & \\
\hline & & A & $\mathrm{C}$ & $\bar{A}$ & $\mathrm{C}$ & A & $\bar{C}$ & $\bar{A}$ & $\mathrm{C}$ \\
\hline CD 215 & 11.2 & 11.4 & 11.1 & 6.8 & 7.0 & 8.3 & 7.0 & 10.0 & 8.1 \\
\hline CD 202 & 13.4 & 11.7 & 11.5 & 7.0 & 7.0 & 8.6 & 7.0 & 9.5 & 8.1 \\
\hline NK 412113 & 11.6 & 11.7 & 11.3 & 6.8 & 7.1 & 8.2 & 7.0 & 10.1 & 7.9 \\
\hline CD 233RR & 12.6 & 11.6 & 11.4 & 6.9 & 7.1 & 8.4 & 7.0 & 10.5 & 7.8 \\
\hline NK 7059RR & 11.2 & 11.7 & 11.3 & 7.0 & 7.0 & 8.1 & 7.0 & 9.6 & 7.6 \\
\hline
\end{tabular}

Alencar et al. (2009) evaluated the soybean stored seeds quality in moisture range of $11.2 ; 12.8$ and $14.8 \%$ w.b., with different relative humidity and temperature values. They observed that for soybean trading, it can be stored for 180 days, seeds with $14.8 \%$ water content at temperatures from 20 to 30 ${ }^{\circ} \mathrm{C}$, but only seeds up to $11.0 \%$ water content may be stored at $40{ }^{\circ} \mathrm{C}$. Cardoso et al. (2004) have evaluated the physiological and sanitary quality of soybean seeds treated with fungicide, stored in a cold system, during eight months. They observed that the seeds on top of stored cells, with $14 \%$ water content, reduced their physiological quality after two months of storage. Alencar et al. (2008) have also verified the quality of soybean seeds stored under different conditions, associated with water content (11.2, 12.8 and 14.8\%) and temperature (20, 30 and $40{ }^{\circ} \mathrm{C}$ ) every 45 days, during 180 storage days. They observed that after 135 days at $20^{\circ} \mathrm{C}$, the germination potential was reduced at $14.8 \%$ water content, since this value can be considered high.

The initial characterization of soybean seeds obtained by the tetrazolium test, just after harvest and before storage, showed that the cultivars were statistically different for both vigor and viability percentages (Table 2). The following cultivars CD 233RR (94\%), NK 7059RR (92\%) and CD 215 $(89 \%)$ showed the highest vigor percentages. They differed significantly from CD 202 and NK412113 cultivars with the least vigor percentages, whose averages were 82 and $80 \%$, respectively. But, concerning to viability, the highest averages were kept for CD 233RR, NK 7059RR and CD 215 (97, 96 and 95\%) cultivars, respectively. According to França Neto, Krzyzanowski and Costa (1999), the vigor level is classified as very low for values bellow 49\%, low for values between 50 and 59\%, medium for values between 60 and 74\%, high for values between 75 and $84 \%$ and very high for values that are equal or superior to $85 \%$. Regarding the seed vigor effects on storage potential, with the inevitable and irreversible deteriorating process, those seeds with high vigor will reach the end of storage period in better condition than the ones with low vigor (CARVALHO, 1994).

Table 2. Average percentages of vigor, viability, 1-8 mechanical damage, 6-8 mechanical damage, 1-8 damage by moisture and 1-8 damage by bedbug attack from five varieties of soybean seeds obtained by tetrazolium test, after harvest.

\begin{tabular}{lllllll}
\hline Varieties & Vigor & Viability & $1-8$ Mechanical & $6-8$ Mechanical & $1-8$ Moisture & $1-8$ Bedbug \\
\hline CD 215 & $89 \mathrm{a}$ & $95 \mathrm{ab}$ & $28 \mathrm{~b}$ & $2 \mathrm{c}$ & $19 \mathrm{~b}$ & $1 \mathrm{~b}$ \\
CD 202 & $82 \mathrm{~b}$ & $92 \mathrm{bc}$ & $49 \mathrm{a}$ & $8 \mathrm{ab}$ & $14 \mathrm{~b}$ & $11 \mathrm{a}$ \\
NK 412113 & $80 \mathrm{~b}$ & $88 \mathrm{c}$ & $30 \mathrm{~b}$ & $9 \mathrm{a}$ & $50 \mathrm{a}$ & $4 \mathrm{~b}$ \\
CD 233 RR & $94 \mathrm{a}$ & $97 \mathrm{a}$ & $20 \mathrm{c}$ & $4 \mathrm{bc}$ & $16 \mathrm{~b}$ & $3 \mathrm{~b}$ \\
NK 7059RR & $92 \mathrm{a}$ & $96 \mathrm{ab}$ & $23 \mathrm{bc}$ & $6 \mathrm{abc}$ & $18 \mathrm{~b}$ & $9 \mathrm{a}$ \\
\hline CV $(\%)$ & 2.95 & 2.06 & 11.67 & 36.71 & 11.55 & 31.94 \\
\hline
\end{tabular}

Averages followed by the same letter in the column do not differ at $5 \%$ probability by Tukey test. The presented data are obtained from the original observations. Moisture damage data did not show normality and were transformed into $\sqrt{\mathrm{x}}+1$. 
Physiological quality...

The results were significant $(\mathrm{P}<0.05)$ for all analyzed variables of damages presented in soybean seeds. There was no presence of moisture damage in 6-8 class or damage to bedbug attack in 6-8 class. The parameters for mechanical damage in 6-8 class, and bedbug damage, 6-8 class, showed the greatest coefficient of variation $(30 \%)$ and data were considered heterogeneous (Table 2). The CD 202 variety showed the highest percentage of mechanical damage in 1-8 class, differing significantly from the others. It was followed by NK 412113, CD 215 and NK 7059RR varieties with statistically equal averages, due to the lowest vigor levels. The lowest damage percentage was verified on CD 233RR, explaining why it was more vigorous. The high percentage of mechanical damage occurrence explains the seed vigor reduction, with the highest damage percentage on CD 202 and NK 412113.

However, it was observed by Palagi (2004) that CD 202 had low lignin content, consequently it was more susceptible to mechanical damage during harvest and seed handling operations than CD 201 variety. This may also explain the fact observed in this study, because CD 202 had low physiological quality. These declining results in germination percentage may reflect the high levels of mechanical damage identified by the tetrazolium test.

Regarding to mechanical damage in 6-8 class, the highest rates were found out in NK 412113, CD 202 and NK 7059 varieties, with statistic similar averages. The CD 215 showed the lowest damage percentage, followed by CD 233RR, which did not differ among themselves and NK 7059RR. The 6-8 levels indicate the loss percentage of seed viability. It is considered without restriction if viability presents answers bellow 6\%; when it varies between 7 and $10 \%$, there is a serious problem, if the results are superior to $10 \%$, there is a very serious problem (FRANÇA NETO et al., 1999). Therefore, in this trial, the CD 202 and NK 412113 varieties showed damage between 7 and $10 \%$ and this is considered as a serious problem.

The highest percentage of damage by moisture, 1-8 class, was found out in NK 412113, which was statistically different from the others, with $50 \%$ damage. The highest rate was found out in CD $202(11 \%)$ and NK 7059RR (9\%) varieties for damage bedbug in 1-8 class, which differed from the others. The lowest percentages of damage levels were presented to CD 215, NK 412113 and CD 233RR varieties, which did not differ by themselves. Costa et al. (2003) observed that soybean seeds with 5\% range of damage by bedbugs did not have vigor level affected. However, up from $6 \%$ incidence, there is a significant reduction in seeds vigor.

No significant differences were observed among soybean varieties using germination before storage. All cultivars showed a good performance with germination percentage above $90 \%$. In the germination test during the storage period, the varieties differed significantly $(\mathrm{P}<0.05)$. The storage conditions were also significant for germination. The 60 and 180 storage days showed no significant interaction among cultivars and storage conditions, whereas the periods 120 and 240 storage days showed some interaction between variables (Table 3). At 60 days, there was difference between the storage conditions for average germination percentage, especially when the storage was under cooling condition, with $4 \%$ more than when in room condition. This would be a cost indicative for keeping cooling. Regarding cultivars, the highest germination was observed for CD 215 (96\%), which differed from CD 202, with the lowest average germination percentage (87\%).

Senem et al. (2014) observed that CD 202 variety showed the lowest germination percentage when compared to CD 215 and CD 233RR, both at room temperature and cooling conditions. After 120 storage days, there was higher average germination percentage under room temperature, for $7059 \mathrm{RR}$ NK (92\%) that differed from CD 202 (78\%), with lower percentage, which was statistically equal to CD 233RR variety (89\%). At cooling conditions, CD 215 and CD 233RR can be highlighted with 97 and 94\% germination, respectively. Storage conditions differed for CD 215, since it presented the best results under cooling conditions, with $6 \%$ more than the environment. According to Smaniotto et al. (2014), the air-conditioned environment (20 ${ }^{\circ} \mathrm{C}$ ) provided the best preservation of physiological quality on soybean seeds, in all analyzed conditions. Demito and Afonso (2009) have already submitted soybean seeds BRS 184 variety to artificial cooling in silos, from 12 to $15{ }^{\circ} \mathrm{C}$, in blocks of 840 bags with $40 \mathrm{~kg}$ each and the other block was kept at room temperature for 140 days. The initial and final soybean seeds germinations were analyzed, and it was observed that the cooled seeds kept a cooling germination after 140 storage days. In general, when they were stored at room temperature (not cooled), soybeans lost their physiological quality. 
Table 3. Average percentages of germination on five varieties of soybean seeds at 60, 120, 180 and 240 storage days under room temperature (RT) and cooling (C).

\begin{tabular}{|c|c|c|c|c|c|c|c|}
\hline \multirow{2}{*}{$\begin{array}{l}\text { Periods } \\
\text { (days) }\end{array}$} & \multirow{2}{*}{ Conditions } & \multicolumn{6}{|l|}{ Varieties } \\
\hline & & CD 215 & CD 202 & NK 412113 & CD 233RR & NK 7059RR & Averages \\
\hline \multirow[t]{2}{*}{0} & RT & 96 & 90 & 93 & 94 & 91 & 92.6 \\
\hline & CV (\%) & 4.38 & & & & & \\
\hline \multirow{4}{*}{60} & RT & 95 & 83 & 92 & 89 & 92 & $90 \mathrm{~B}$ \\
\hline & $\mathrm{C}$ & 97 & 90 & 95 & 94 & 97 & $94 \mathrm{~A}$ \\
\hline & Averages & $96 a$ & $87 \mathrm{~b}$ & $94 \mathrm{ab}$ & $89 a b$ & $95 a$ & \\
\hline & CV (\%) & 6.62 & & & & & \\
\hline \multirow{3}{*}{$120 *$} & RT & $91 \mathrm{aB}$ & $78 \mathrm{bA}$ & $90 \mathrm{aA}$ & 89abA & $92 \mathrm{aA}$ & \\
\hline & $\mathrm{C}$ & $97 \mathrm{aA}$ & $77 \mathrm{cA}$ & $85 \mathrm{bcA}$ & $94 \mathrm{abA}$ & $91 \mathrm{bA}$ & \\
\hline & $\mathrm{CV}(\%)$ & 6.82 & & & & & \\
\hline \multirow{4}{*}{180} & RT & 95 & 79 & 88 & 92 & 92 & $89 \mathrm{~A}$ \\
\hline & $\mathrm{C}$ & 96 & 80 & 93 & 95 & 92 & $91 \mathrm{~A}$ \\
\hline & Averages & $96 a$ & $80 \mathrm{~b}$ & $91 \mathrm{a}$ & $94 \mathrm{a}$ & $92 \mathrm{a}$ & \\
\hline & $\mathrm{CV}(\%)$ & 5.21 & & & & & \\
\hline \multirow{3}{*}{$240 *$} & RT & 93abA & $80 \mathrm{cA}$ & $87 \mathrm{bcA}$ & $98 \mathrm{aA}$ & $93 \mathrm{abA}$ & \\
\hline & $\mathrm{C}$ & $92 \mathrm{aA}$ & $75 \mathrm{bA}$ & $92 \mathrm{aA}$ & $89 a B$ & $92 \mathrm{aA}$ & \\
\hline & $\mathrm{CV}(\%)$ & 4.61 & & & & & \\
\hline
\end{tabular}

Note: Averages followed by the same lower case letter in the row indicate the same averages among varieties. The same capital letter in the column indicates the same averages under storage conditions. At 60 and 180 days, there was no significant interaction between varieties and storage conditions at $5 \%$ probability by Tukey test. * At 120 and 240 days, there was no significant interaction. Averages followed by the same lower case letter in the row indicate the same averages among varieties, and the same capital letters in column indicate the same averages between storage conditions at $5 \%$ probability by Tukey test.

The seed storage under cooling favors controlled environmental conditions (low temperature and/or relative humidity), which allows keep them for long periods. This provides no changes under moisture conditions during storage, preventing moisture absorption from the air by the seeds, which would lead to an increase on water content to limits that can affect their quality (PESKE; ROSENTHAL; ROTA, 2003). At 180 days, the germination percentage did not differ between cooling and room temperature. When varieties were compared, the CD 202 showed the lowest germination percentage $(80 \%)$, with statistical difference from the others. The seeds germination percentage remained stable over the period, and this might have happened because water content was below 14\% (Table 1). This also was confirmed by Alencar et al. (2008) who observed that at $20{ }^{\circ} \mathrm{C}$, the germination potential of seeds with $14.8 \%$ water content was reduced. This occurred because it was too high, which increases seed deterioration due to respiratory rate increase.

At 240 days in room temperature condition, the CD 233RR showed the highest germination percentage, which differed significantly from the CD 202 and NK 412113 varieties, with 80 and 87\% averages, respectively. Only the CD 202 (75\%) differed from the others, on cooling, with the lowest average again, below the minimum acceptable standard for trading (80\%) (SEAB, 2005). Statistically significant difference is observed between the storage conditions for the germination percentage only in CD 233RR variety, highlighting the room temperature condition with the highest average: 9\% more than cooling. These results corroborated with Minuzzi et al. (2010), which observed that CD 202 variety also showed lower answers to germination and accelerated aging test. The reduction of seeds water content during storage allowed varieties to maintain satisfactory germination until the end of storage, except CD 202 variety, which up from the beginning had shown some reduction in germination.

Suguiy (2005) evaluated the soybean seeds quality stored for 12 months in conventional and cooled storehouse, by tests of germination, vigor by tetrazolium and accelerated aging. He observed that the cooled storehouse showed the best answers for germination and vigor when compared to conventional and aluminum lining storehouse, although the differences in temperature between storage systems showed no significant difference. The varieties differed significantly for both germination and viability (tetrazolium test) in periods longer than 60 days. The storage conditions were significant at 60,180 and 240 storage days. There was no significant interaction in the evaluated periods, only the viability was significant (Table 4). There was difference between the storage conditions at 60 days, mainly for cooling, which was 7\% higher than room temperature condition. Regarding varieties, there was no statistical difference. 
At 120 storage days, there was no difference between storage conditions for viability. The CD 202 variety showed lower viability, with $79 \%$ of viable embryos in tetrazolium test, differing from the others. At 180 days, the storage conditions differed from each other, especially in cooling, with $4 \%$ viability higher than the room temperature condition. Regarding the studied varieties, the ones that showed the highest viability percentage were again NK 7059RR, CD 215 and CD 233RR, as at 120 days. The CD 202 and NK 412113 were statistically the same, with the lowest viability values, which can also be checked in results of vigor test

(Table 2).

Table 4. Average percentages on soybean seed viability of varieties, obtained by tetrazolium test in four storage periods under room temperature (RT) and cooling (C) conditions.

\begin{tabular}{|c|c|c|c|c|c|c|c|}
\hline \multirow{2}{*}{$\begin{array}{l}\text { Periods } \\
\text { (days) }\end{array}$} & \multirow{2}{*}{ Conditions } & \multicolumn{6}{|l|}{ Varieties } \\
\hline & & CD 215 & CD 202 & NK 412113 & CD 233RR & NK 7059RR & Averages \\
\hline \multirow{4}{*}{60} & RT & 93 & 87 & 87 & 94 & 94 & $91 \mathrm{~B}$ \\
\hline & $\mathrm{C}$ & 99 & 98 & 96 & 98 & 100 & $98 \mathrm{a}$ \\
\hline & Averages & $96 a$ & $93 a$ & $92 a$ & $96 a$ & $97 a$ & \\
\hline & $\mathrm{CV}(\%)$ & 2.67 & & & & & \\
\hline \multirow{4}{*}{120} & RT & 93 & 79 & 88 & 92 & 92 & $89 a$ \\
\hline & $\mathrm{C}$ & 93 & 78 & 89 & 84 & 96 & $88 \mathrm{a}$ \\
\hline & Averages & $93 a$ & $79 b$ & $89 a$ & $88 \mathrm{a}$ & $94 a$ & \\
\hline & $\mathrm{CV}(\%)$ & 7.62 & & & & & \\
\hline \multirow{4}{*}{180} & RT & 87 & 76 & 76 & 91 & 94 & $85 \mathrm{~B}$ \\
\hline & $\mathrm{C}$ & 94 & 82 & 83 & 92 & 94 & $89 a$ \\
\hline & Averages & $91 \mathrm{a}$ & $79 \mathrm{~b}$ & $80 \mathrm{~b}$ & $92 a$ & $94 a$ & \\
\hline & CV (\%) & 4.69 & & & & & \\
\hline \multirow{4}{*}{240} & RT & 84 & 69 & 69 & 88 & 90 & $80 \mathrm{~B}$ \\
\hline & $\mathrm{C}$ & 93 & 76 & 81 & 90 & 89 & $86 a$ \\
\hline & Averages & $94 a$ & $73 b$ & $75 b$ & $89 a$ & $90 \mathrm{a}$ & \\
\hline & $\mathrm{CV}(\%)$ & 4.75 & & & & & \\
\hline
\end{tabular}

Averages followed by the same capital letter in column do not differ for the same storage conditions and in row, they do not differ in varieties by Tukey test at $5 \%$ probability. Data presented are obtained from the original observations. Data that were not normal in periods of 120,180 and 240 days were transformed into $\sqrt{\mathrm{x}}+1$.

The storage conditions differ at 240 days for viability. It is observed the best performance under cooling, with $6 \%$ more than under room temperature condition. The CD 215 showed the highest viability without differing from CD 233RR and NK 7059RR. The varieties with the lowest viability were, again, CD 202 and NK 412 113, that showed statistically the same answers. These results were similar at 180 days' period. The cooling condition resulted in better answers for seeds viability. This is probably because in controlled environment there are no constant changes in temperature and humidity, which is advantageous for seeds so they can keep stable. Even the seeds water content has reduced during storage, it did not affect the seeds viability in both conditions. This was observed for those more vigorous seeds, such as CD 215, CD 233RR and NK 7059RR.

Soybean stored at room temperature and cooling conditions showed aflatoxin presence. The greatest presence was detected in CD 202 variety, so, from the 16 tested samples, 10 of them showed some level of aflatoxin contamination. The AFB1 presence was observed in storage cooling conditions in 120 days (one sample), 180 days (one sample), and 240 days (two samples). It was observed contamination by AFG2 in the same periods, but at 120 days, a contaminated sample was verified at room temperature, and at 180 days, two contaminated samples were observed under cooling and at 240 days, one contaminated sample was observed at room temperature. Two contaminated samples were also observed under cooling, totalizing, between B1 and $\mathrm{G} 2$, ten contaminated samples. It was observed, in CD 202, that $63 \%$ of samples were contaminated by AFG2, while 50\% were by AFB1 (Table 5).

The NK 7059 RR variety did not show aflatoxin contamination, while CD 215 variety presented in just one sample with AFG2 at 120 storage days under cooling. In NK 412113, two aflatoxins were detected in four tested soybean samples (2AFB1 and 2 AFG2 at 60 storage days at room temperature), representing $25 \%$ for the analyzed samples. It was close to that answer recorded for CD 233 RR variety, which presented 
$19 \%$ of the samples contaminated with AFB1 and AFG2 aflatoxins. This means that, there was contamination at both 120 and 240 days. At 120 days, under cooling conditions and at 240 days at room temperature for $\mathrm{AFB} 1$, and for $\mathrm{AFG} 2$, there was a contaminated sample at 240 days at room temperature.

Table 5. Results of analysis of aflatoxin presence in soybean varieties according to the studied storage conditions, room temperature and cold during five periods.

\begin{tabular}{|c|c|c|c|c|c|c|c|}
\hline Aflatoxin & \multirow{2}{*}{$\begin{array}{l}\text { Periods } \\
\text { (days) }\end{array}$} & \multirow{2}{*}{ Conditions } & \multicolumn{5}{|c|}{ Varieties } \\
\hline \multirow{11}{*}{ B1 } & & & CD 215 & CD 202 & NK 412113 & CD 233RR & NK 7059RR \\
\hline & \multirow{2}{*}{0} & 0 & nd & nd & 5 & nd & nd \\
\hline & & 0 & nd & nd & nd & nd & nd \\
\hline & \multirow{2}{*}{60} & RT & nd & nd & 2 & nd & nd \\
\hline & & $\mathrm{C}$ & nd & nd & nd & nd & nd \\
\hline & & RT & nd & nd & nd & nd & nd \\
\hline & 120 & $\mathrm{C}$ & nd & 1 & nd & 1 & nd \\
\hline & \multirow{2}{*}{180} & RT & nd & nd & nd & nd & nd \\
\hline & & $\mathrm{C}$ & nd & 1 & nd & nd & nd \\
\hline & \multirow{2}{*}{240} & RT & nd & nd & nd & 1 & nd \\
\hline & & $\mathrm{C}$ & nd & 2 & nd & nd & nd \\
\hline \multirow{10}{*}{$\mathrm{B} 2$} & \multirow{2}{*}{0} & 0 & nd & nd & nd & nd & nd \\
\hline & & 0 & nd & nd & nd & nd & nd \\
\hline & \multirow{2}{*}{60} & RT & nd & nd & nd & nd & nd \\
\hline & & $\mathrm{C}$ & nd & nd & nd & nd & nd \\
\hline & \multirow{2}{*}{120} & RT & nd & nd & nd & nd & nd \\
\hline & & $\mathrm{C}$ & nd & nd & nd & nd & nd \\
\hline & \multirow{2}{*}{180} & RT & nd & nd & nd & nd & nd \\
\hline & & $\mathrm{C}$ & nd & nd & nd & nd & nd \\
\hline & \multirow{2}{*}{240} & RT & nd & nd & nd & nd & nd \\
\hline & & $\mathrm{C}$ & nd & nd & nd & nd & nd \\
\hline \multirow{10}{*}{$\mathrm{G} 2$} & \multirow{2}{*}{0} & 0 & nd & nd & 5 & nd & nd \\
\hline & & 0 & nd & nd & nd & nd & nd \\
\hline & \multirow{2}{*}{60} & RT & nd & nd & 2 & nd & nd \\
\hline & & $\mathrm{C}$ & nd & nd & nd & nd & nd \\
\hline & \multirow{2}{*}{120} & RT & nd & 1 & nd & nd & nd \\
\hline & & $\mathrm{C}$ & 1 & nd & nd & nd & nd \\
\hline & \multirow{2}{*}{180} & RT & nd & nd & nd & nd & nd \\
\hline & & $\mathrm{C}$ & nd & 2 & nd & nd & nd \\
\hline & \multirow{2}{*}{240} & RT & nd & 1 & nd & 1 & nd \\
\hline & & $\mathrm{C}$ & nd & 2 & nd & nd & nd \\
\hline
\end{tabular}

$\mathrm{RT}=$ room temperature; $\mathrm{C}=$ cold, $\mathrm{nd}=$ no detected.

Overall, 90 samples were tested and of these, in 25 of them, aflatoxin presence was detected. All studied varieties showed higher levels in relation to the tolerated limit by Mercosur, ie greater than $5 \mathrm{\mu g} \mathrm{kg}^{-1}$ (ANVISA, 2011). The highest level was observed in NK 4112113 variety sample with $297.56 \mu \mathrm{g} \mathrm{kg}^{-1}$, and the lowest level, but still above the limit tolerated for food security, was 8.22 $\mu \mathrm{g} \mathrm{kg}{ }^{-1}$, corresponding to CD $233 \mathrm{RR}$ sample variety. Mallman et al. (2003) analyzed 554 samples of soybeans according to aflatoxins occurrence. And $16.24 \%$ were positive for aflatoxin, but only two of them showed values above the upper limit recommended by Mercosur $\left(20 \mu \mathrm{g} \mathrm{kg}^{-1}\right)$.

According to a research conducted by Oliveira, Loreni e Mallmann (2010), soybean samples were evaluated when receiving and shipment of a storage unit of grains. The results showed low occurrence of mycotoxins. This is due to the fact that they were stored properly, which proves the assertion of Elias and Oliveira (2009) that pre-cleaning and drying are essential items for safe storage of grains and seeds. Sassahara, Yanaka e Pontes Netto (2003) quantified aflatoxins in diets for dairy cattle and found out that from 85 samples 
Physiological quality...

of commercial feed tested, 17 (20\%) of them registered the presence of aflatoxins and from these ones, eight (47\%) were above $20 \mu \mathrm{g} \mathrm{kg}^{-1}$ allowed by ANVISA. Whereas, from the 12 prepared diet samples analyzed, 67\% showed levels above the recommended ones. However, based on the 13 diets with soybean meal in their composition, positive results for aflatoxins were found out in only one.

It is observed that although there is prior knowledge that fungi incidence is given in high temperature and humidity function, consequently, there was no significance between the storage conditions for the aflatoxin presence. The samples showed dispersed behavior, so it was not possible to correlate the highest or the lowest incidence according to the environment whose soybeans remained until their evaluation. It can be highlighted that CD 202 variety showed significant numbers in relation to the others. There were 10 samples contaminated with aflatoxin, and only one of them was stored at room temperature, simulating a storehouse. However, this fact cannot be attributed to a response from the storage condition since the other varieties have not presented the same behavior.

Guerino et al. (2013) did not detect aflatoxin B1 in the organic and conventional soybean storage, however, fungi proliferation observed during the exposure time of two soybean varieties. Kobashigawa (2010) observed the occurrence of aflatoxin in broiler production system and observed that there was no significant aflatoxin incidence when the raw material used in the diets was soybeans. Acunã et al. (2005) have analyzed samples of the components in diets for animals, and observed some contamination by Fusarium in 100\% of corn and cottonseed meal, and $80 \%$ in sorghum and soybeans samples. Nones (2010) also worked with swine diet and found out that from the fortyfour of the tested samples, none of them detected mycotoxins presence, except Fusarium, both in ingredients (corn, soybean, rice bran) and in the diet. The author further states that, although there were moisture and temperature in the storehouse where the diet was stored, there was no ventilation, which explains the non-proliferation of fungi in this environment.

\section{NÓBREGA, L. H. P. et al}

Overall, CD 202 variety showed the lowest rates of germination and viability over the storage periods and at the initial rating, there was a high 1-8 mechanical damage and 1-8 bedbug attack. This was also the variety that showed the highest contamination by aflatoxin, in such a way that damages associated to seeds favored these results.

\section{CONCLUSIONS}

CD 233RR variety showed the best storage potential. Seeds stored in different conditions have different behavior according to vigor after 120 days' storage. There is no difference from the seeds vigor for both conventional or transgenic ones.

Taking into account that the germination test is valid for six months, all varieties have shown a good performance two months after the expiry date, except for CD 202 variety. Considering the studied storage period of eight months, it can be pointed out that the cooling conditions kept vigor of CD 215 and CD 233RR varieties until the end of the period.

During the analysis it was detected the presence of AFB1, AFB2 and AFG2 aflatoxin. They showed results above the tolerable limit for Mercosur legislation, which considers levels above $5 \mu \mathrm{g} \mathrm{kg}^{-1}$ not acceptable for food security. It was concluded that there was no influence by the storage as there was no discrepancy or correlation data for aflatoxin ratio and temperature. However, it is known that the water content provides high temperatures associated with the fungi development, which caused mycotoxins occurrence. Therefore, it can be assumed that the detected presence of aflatoxins was still in the field, which it is very common when water content is high.

This research aimed at the prevention of mycotoxins, still in the field, are necessary in order to ensure food security, since soybean is consumed in large scale worldwide. Controlling the fungi incidence in the field, the chances of minimizing the occurrence in post-harvest are more efficient when the humidity and temperature factors are easier to manipulate.

RESUMO: A qualidade fisiológica de sementes de soja de cinco cultivares (CD 215, CD 202, CD 233RR (GMO), NK e NK 412113 7059RR (GMO)), armazenadas sob resfriamento e temperatura ambiente durante oito meses, bem como a prevalência de aflatoxinas B1, B2 e G2 foram avaliadas. Os testes (teor de água, germinação, tetrazólio) foram antes do armazenamento e a cada 60 dias, assim como a presença de aflatoxinas. Duas amostras de cada cultivar foram armazenadas a $-4{ }^{\circ} \mathrm{C}$ até o momento da análise em cromatografia líquida. As sementes mostraram, em geral, teor de água entre 11 e $13 \%$ nos 60 dias de 
armazenagem, decrescendo aos 120 dias. Aos 60 dias, as sementes resfriadas apresentaram alta germinação quando comparadas àquelas em temperatura ambiente. Quanto às cultivares, maior germinação foi verificada na CD 215, a qual diferiu da CD 202 em ambos os períodos. Houve interação entre os fatores depois de 120 e 240 dias de armazenagem para a CD 215. Enquanto, aos 240 dias em temperatura ambiente a maior germinação foi para a CD 233 RR. As condições de armazenamento foram significativas aos 60, 180 e 240 dias para viabilidade, com maior taxa verificada sob resfriamento. Quanto às cultivares, nos mesmos períodos, a CD 202 mostrou viabilidade mais baixa, junto da NK 412113 depois de 180 e 240 dias. Foram testadas 90 amostras e em 25 foi detectada a presença de aflatoxinas. Na cultivar CD 202 a quantidade foi maior. De 16 amostras testadas, dez apresentaram algum nível de contaminação por aflatoxina. As aflatoxinas AFB1 e AFB2 representaram 50\%, e na AFG2 foi observada em $63 \%$ das amostras. Não houve diferença quanto ao vigor entre sementes convencionais ou transgênicas. O resfriamento manteve o vigor das CD 215 e CD $233 R R$ até o final. Em geral, não foi associada maior presença de aflatoxinas às condições de armazenamento testadas.

PALAVRAS-CHAVE: Germinação. Glycine max (L.) Merrill. Micotoxinas. Temperatura.

\section{REFERENCES}

ACUÑA, A.; LOZANO, M. C.; GARCIA, M. C. de; DIAZ, G. J. Prevalence of Fusarium species of the Liseola section on selected Colombian animal feedstuffs and their ability to produce fumonisins. Mycopathologia, Berkeley, v. 160, N. 1, p. 63-66, 2005. https://doi.org/10.1007/s11046-005-1590-0

ALENCAR, E. R.; FARONI, L. R. D.; LACERDA FILHO, A. F.; FERREIRA, L. F.; MENEGHITTI, M. R. Qualidade dos grãos de soja em função das condições de armazenamento. Engenharia na Agricultura, Viçosa, v. 16, n. 2, p. 155-166, 2008.

ALENCAR, E. R.; FARONI, L. R. D.; LACERDA FILHO, A. F.; PETERnELli, L. A.; COSTA, A. R. Qualidade dos grãos de soja armazenados em diferentes condições. Revista Brasileira de Engenharia Agrícola e Ambiental, Campina Grande, v. 13, n. 5, p. 606-613, 2009. https://doi.org/10.1590/S141543662009000500014

ANVISA - Agencia Nacional de Vigilância Sanitária. INSTRUÇÃO NORMATIVA No 46, DE 18 DE FEVEREIRO DE 2011. Dispõe sobre limites máximos tolerados (LMT) para micotoxinas em alimentos. Diário Oficial da União, Brasília, 09 mar. 2011. Seção 1, p. 66.

AOAC 994.08. Official Methods of Analysis of AOAC. Aflatoxins in corn, almonds, Brazil nuts, peanuts, and pistachio nuts, multifunctional column (Mycosep) method. 17 ed, v. II, AOAC International, Gaithersburg, Maryland, USA Natural toxins-chapter 49. p. 26-27, 2000.

BRASIL. Ministério da Agricultura, Pecuária e Abastecimento. Regras para análise de sementes / Ministério da Agricultura, Pecuária e Abastecimento. Secretaria de Defesa Agropecuária. - Brasília: Mapa/ACS, 2009. $399 \mathrm{p}$.

CARDOSO, P. C.; BAUDET, L.; PESKE, S. T.; LUCCA FILHO, O, A. Armazenamento em sistema a frio de sementes de soja tratadas com fungicida. Revista Brasileira de Sementes, Londrina, v. 26, n. 1, p. 15-23, 2004. https://doi.org/10.1590/S0101-31222004000100003

CARRÃO-PANIZZI, M. C.; MANDARINO, J. M. G. Soja: potencial de uso na dieta Brasileira. Londrina: Embrapa CNPSo, 1998. 16 p. (EMBRAPA CNPSo. Documentos, 113).

CARVALHO, N. M. O conceito de vigor em sementes. In: VIEIRA, R. D., CARVALHO, N. M. Testes de vigor em sementes. Jaboticabal: FUNEP, 1994. p. 1-30. 
CAVALIERE, C.; FOGLIA, P.; GUARINO, C.; MOTTO, M.; NAZZARI, M.; SAMPERI, R.; LAGANÁ, A.; BERARDO, N. Mycotoxins produced by Fusarium genus in maize: determination by screening and confirmatory methods base on liquid chromatography tandem mass spectrometry. Food Chemistry, Norwich, v. 105, n. 2, p. 700-710, 2007. https://doi.org/10.1016/j.foodchem.2006.12.057

COSTA, N. P.; MESQUITA, C. M.; MAURINA, A. C.; FRANÇA NETO, J. de B.; KRZYZANOWSKI, F. C.; HENNING, A. A. Qualidade fisiológica, física e sanitária de sementes de soja produzidas no Brasil. Revista Brasileira de Sementes, Londrina, v. 25, n. 1, p. 128-132, 2003. https://doi.org/10.1590/S010131222003000100020

DEMITO, A; AFONSO, A. D. L. Qualidade das sementes de soja resfriadas artificialmente. Revista Engenharia na Agricultura, Viçosa, v. 17, n. 1, p. 7-14, 2009.

ELIAS, M. C.; OLIVEIRA, M. Aspectos tecnológicos e legais na formação de auditores técnicos do sistema nacional de certificação de unidades armazenadoras. Pelotas: Super Copías Santa Cruz, 2009. 430p.

FRANÇA NETO, J. de B.; PEREIRA, L. A. G.; COSTA, N. P. da; KRZYZANOWSKI, F. C. ; HENNING, A. A. Metodologia do teste do tetrazólio em semente de soja. Londrina, EMBRAPA-CNPSo, p. 60, Documentos 32, 1988.

FRANÇA NETO, J. B.; KRZYZANOWSKI, F. C.; COSTA, N. P. Vigor de sementes: Conceitos e Testes. ABRATES. Londrina, p. 8.5-3, 1999.

FERREIRA, D. F. SISVAR: um programa para análises e ensino de estatística. Revista Científica Symposium, Lavras, v. 6, n. 2, p. 36-41, 2008.

GUERINO, D.; SCHEUFELE, F. B.; HASAN, S. D.; FIORESE, M. L. Condições de armazenamento das sojas orgânica e convencional sobre suas qualidades química e microbiológica. Revista Brasileira de Produtos Agroindustriais, Campina Grande, v. 15, n. 1, p. 69-79, 2013. https://doi.org/10.15871/15178595/rbpa.v15n1p69-79

HARRINGTON, J. F. Seed storage and longevity. In: Kozlowski, T. T. (ed.). Seed biology. New York: Academic Press, 1972. p. 145-245.

KOBASHIGAWA, E. Ocorrência de aflatoxinas e fumonisinas em sistema de produção de frangos de corte no Estado de São Paulo. 2010. 114 f. Tese (Doutorado) - Faculdade de Zootecnia e Engenharia de Alimentos, Universidade de São Paulo, Pirassununga, 2010.

KONG, F.; CHANG, S. K.; LIU, Z.; WILSON, L. A. Changes of soybean quality during storage as related to soymilk and tofu making. Journal of Food Science, Medford, v. 73, n. 3, p. 134-135, 2008. https://doi.org/10.1111/j.1750-3841.2007.00652.x

LUZ, M. L. G. S. Importância de medir a umidade dos grãos. Revista Campo \& Negócios. Uberlândia, Ano IV, n. 48, p. 42-44, 2007.

MALlmanN, C. A.; MURMAMM, L.; DILKIN, M.; DILKIN, P. Prevalência de aflatoxinas em soja. Laboratório de Análises Micotoxicológicas, UFSM. Santa Maria - RS, 2003. Disponível em: http://www.lamic.ufsm.br/papers/13a.pdf. Acesso em 12 de jan de 2012.

MAPA - Ministério da Agricultura, Pecuária e Abastecimento. Soja transgênica. Disponível em: www.agricultura.gov.br. Acesso em: 14 de Agosto de 2012. 
MINUZZI, A.; BRACCINI, A. de L.; RANGEL, M. A. S.; SCAPIM, C. A.; BARBOSA, M. C.; ALBRECHT, L. P. Qualidade de sementes de quatro cultivares de soja, colhidas em dois locais no estado do Mato Grosso do Sul. Revista Brasileira de Sementes, Londrina, v. 32, n. 1, p. 176-185, 2010. https://doi.org/10.1590/S010131222010000100020

MURMANN, L.; KOWALSKI, C. H.; ARAUJO, D. D. F.; DILKIN, M.; DILKIN, P.; MALlMANN, A. C. Avaliação dos índices de contaminação por aflatoxinas em soja consumida no Estado do Rio Grande do Sul. Laboratório de Análises Micotoxicológicas, UFSM. Santa Maria - RS, 2007. Disponível em: http://www.lamic.ufsm.br/papers/114z.pdf. Acesso em 12 de jan de 2012.

NONES, J. Avaliação da contaminação por micotoxinas em ingredientes e rações para suínos. Estágio supervisionado - Universidade Federal de Santa Catarina. Florianópolis. 2010.

OLIVEIRA, M. A.; LORINI, I.; MALLMANN, C. A. As micotoxinas e a segurança alimentar na soja armazenada. Micotoxins and food safety in soybeans storage. Brazilian Journal of Food Technology, Campinas, III SSA, p. 87-91, 2010.

PALAGI, A. C. Embebição de sementes de soja para o teste de germinação. Dissertação (Mestrado). Universidade Estadual do Oeste do Paraná, Marechal Candido Rondon, PR, 2004.

PENHA, L. A. O.; FONSECA, I. C. de B.; MANDARINO, J. M.; BENASSI, V. de T. A soja como alimento: valor nutricional, benefícios para a saúde e cultivo orgânico. Boletim Ceppa, Curitiba, v. 25, n. 1, p. 91-102, 2007.

PESKE, S. T; ROSENTHAL, M. D; ROTA, G. R M. Sementes: fundamentos científicos e tecnológicos. 1. ed. Pelotas, p. 30-34, 2003.

PIMENTEL GOMES, F. Estatística experimental, 14 ed., Piracicaba: Degaspar, 2000.

SASSAHARA, M., YANAKA, E. K., PONTES NETTO, D. Ocorrência de aflatoxina e zearalenona em alimentos destinados ao gado leiteiro na Região Norte do Estado do Paraná. Semina: Ciências Agrárias, Londrina, v. 24, n. 1, p. 63-72, 2003. https://doi.org/10.5433/1679-0359.2003v24n1p63

SEAB. Secretaria da Agricultura e Abastecimento. Padrões para produção e comercialização de sementes de soja. 2005. Disponível em: http://www.seab.pr.gov.br/arquivos/File/PDF/padroes_soja.pdf.

SENEN, J.; NÓBREGA, L. H. P.; SOCELA, R.; SPIASSI, A.; PACHECO, F. P. GASPARIN, M. B.; CRUZSILVA, C. T. A. da Storage conditions on germination and seeds vigor of conventional and transgenic soybean cultivars. Journal of Agronomic Sciences, Umuarama, v. 3, n. 2, p. 70-79, 2014.

SHABIR, G. A. Validation of high-performance liquid chromatography methods for pharmaceutical analysis. Understanding the differences and similarities between validation requirements of the US food and drug administration, the US pharmacopeia and the International Conference on harmonization. Journal of Chromatography A, v. 987, n. 1-2, p. 57-66, 2003. https://doi.org/10.1016/S0021-9673(02)01536-4

SILVA, J. S.; LACERDA FILHO, A. F.; DEVILHA, I. A. Aeração de grãos armazenados. In: SILVA, J. S. Secagem e armazenagem de produtos agrícolas. Ed. Aprenda Fácil. 1.ed. Viçosa, p. 326-329, 2000.

SMANIOTTO, T. A. S., RESENDE, O.; MARÇAL, K. A. F.; OLIVEIRA, D. E. C.; SIMON, G. A. Qualidade fisiológica das sementes de soja armazenadas em diferentes condições. Revista Brasileira de Engenharia Agrícola e Ambiental, Campina Grande, v. 18, n. 4, p. 446-453, 2014. https://doi.org/10.1590/S141543662014000400013

SUGUIY, M. M. T. Análise térmica de diferentes armazéns (convencional, climatizado e com forro de alumínio) na armazenabilidade de sementes de soja (Glycine max (L.) Merril). 53f. Dissertação (Mestrado em Agronomia) - Universidade Estadual do Oeste do Paraná, Marechal Cândido Rondon, Paraná, 2005. 